\title{
Issues and Challenges in Academic Advising: A Multivriate Study of Students' Attitudes towards Academic Advising in United Arab Emirates (UAE)
}

\author{
Vijaya Kumar Gudep \\ Skyline College \\ Email: vijayakumargudep@gmail.com
}

\begin{abstract}
The contemporary pressures of Globalization arising out of new communications, Information Technology (IT) and scientific progress have a tremendous bearing on designing of effective academic advising systems. The present research study investigates the UAE undergraduate students' attitude towards the issue of academic advising and tests whether a significant difference exists between the attitudes of three types of respondents chosen for this study. An instrument for measuring the attitudes of the students towards academic advising is developed. A sample of size of 482 students is chosen and a research framework is constructed to extract relevant factors affecting students' attitudes towards academic advising.
\end{abstract}

Keywords: Academic Advising, Principal Components Analysis, Factor Loadings, Eigen Value, Rotated Component Matrix-Test and Analysis of Variance

\section{INTRODUCTION}

The contemporary pressures of Globalization arising out of modern communications, Information Technology (IT) and scientific progress have tremendous bearing on modern university curriculum, classroom management, and academic advising delivery systems. In the recent years, the administration of academic advising underwent a radical transformation on account of the technological developments which have altered the processes by which student information is collected, stored, and accessed (Watkins, 1990).Over the past few decades, education administrators and conscientious academic advisors have put forth efforts to meet the needs and concerns of students to deliver 
optimum student satisfaction (Hendey, 1999). Since academic advisors have a unique opportunity to reach the diverse set of students they advise, the usage of traditional practices have less relevance in the technologically driven and student service-oriented environment in which face-to-face services are replaced by technology. In this context, designing effective academic advising systems has emerged as major academic intervention towards reaching the goals of learner-centered education (Vijaya, 2005).The contemporary delivery of academic advising will be increasingly in the form of distant and virtual contacts, less restrained by office hours and staff availability and call for modifications in the forms and functions of traditional academic advising delivery (Scott, 2000). The present research article focuses on the importance of understanding the attitudes of undergraduate students towards academic advising in United Arab Emirates (UAE) and throws light on the relevance of efficient academic advising systems in the technologically dynamic educational environment.

The changing landscape created by this technological revolution has provoked new ways of thinking about the delivery of services typically found in a college's academic advising services portfolio. Several factors will determine the role that technology will play in the management of advising services. For example, the submission of a paper transcript to a college or university will soon be a relic of past practices, as online applications and electronic submission processes are gaining importance. Scanning devices will prescreen and categorize the applications, according to predefined institutional criteria. Likewise, electronic submission of college transcripts will enable the direct entry of student information into the campus records system, without the need for data-entry personnel.

There is an increasing boy of research which revealed that students often meet academic advisors for reasons other than academic issues and concerns (Brown ,2003), Edwards\&Murdock (1994) and McConnell (2000)). Several critics argued that academic advising often becomes a mechanical matching of advisers and advisees, and therefore sometimes advisors end up performing their advising service without direction and support. In this context, Habley (1981) noted that academic advising is instrumental in the fight against student attrition and further opined that " academic advising is the only structured service on the campus by which all students will have an opportunity for an on-going and one-to-one contact with the concerned representative of the institution."

Technological advances are fundamentally changing the way colleges and universities operate and have implications for the management and delivery of advising 
services. Research studies revealed that these technological innovations have created an abundance of opportunities for new practices and enhanced the quality of services which are popularly characterized as 'real-time,' 'student-centered,' and 'any time/ any place' (Moneta, 1997, p. 7). Instead of seeking extended hours for academic advising, students can now submit e-mail inquires that are answered by peer and professional advisers, depending on the nature of the question and the level of expertise required. This has resulted in the creation of an electronic triage system, similar to the one installed at the University of Buffalo (USA), popularly known as the 'Student Response Center, among the students. The UB Student Response Center at University of Buffalo (http://src.buffalo.edu/) consists of the customer service staff from the faculty offices of academic advising. World Wide Web (WWW) access methods now allow for a userdirected applications and interventions. Students, for example, can now review their transcripts, degree audits, and billing status, all from any time and any where through internet. Advising services staff have to reckon with these current challenges and in this context, conversion to the usage of technology will increase the efficiency of service and student satisfaction.

\section{LITERATURE REVIEW}

There is an increasing body of research which highlighted the various issues involved in devising effective academic advising systems. Several research studies abound, the studies made by Light (2001), Davis and Cooper (2001), Milem et al (2000), Alexitch (2002), Hamrick, Evans, \& Schuh, (2002), Kadar (2001), Brown (2003), Walters (2003) and Whelley et al (2003) have predominantly influenced the present study. In this context, Light (2001) established a relationship between academic advising and students' academic growth and stated that "good academic advising can have a profound impact on the academic growth of students" (p. 15). He also observed that such interactions may help a student find his or her place within the university and may also give a more satisfying college experience. Davis and Cooper (2001) elaborated this point by stating that academic advising is one of the systematic and structured services on the campus that facilitates lively interaction with the college administration. It was also observed that the time spent outside of the classroom with students is part of a faculty member's duties and responsibilities and therefore has a profound effect on the academic growth of students (Milem et al 2000). Alexitch (2002) opined that the interactions that students have with faculty members can "increase the intrinsic value that students place 
on learning" (p. 5). She further stated that "this contact may help the student in adjusting to the university climate, cope up with academic difficulties and progress towards academic programs and careers" (p. 5). According to Light (2001), students who interact with faculty members will have fewer difficulties in orienting themselves towards the university curriculum. These ideas are popularly known as "Mattering Theory", which states that students will succeed, if they know that someone in the university cares about them (Hamrick et al, 2002). Likewise, academic advisers can help students to feel confident and pragmatic in discussing academic goals or personal issues that may be affecting their success (Kadar, 2001). Students may feel more relaxed while sharing with their adviser/counselor about the personal life problems, psychological issues and all other academic issues. He further stated that "the advising process provides an opportunity to guide students in setting and achieving their goals" (p. 174). Although a majority of the instructors are aware that the intellectual development of students may vary, sometimes they may fail to approach the course content as desired (Brown, 2003).He further opined that peer advising programs extend the scope and availability of academic advising programs by providing advising through the selected students. In this context, he further stated that peer advisors form close mentoring relationships with their supervisors and may enable them develop leadership skills through their past experiences in the academic advising program. He also felt that these skills benefit peer advisors not only while they are advising, but also after they graduate as they carry this experience to their work place as well. Walters (2003) found peer advising turns out to be an important factor for student success. McConnell (2000) opined that peer advising assists first generation college students' smooth transition in to the academic environment (p.82). Whelley et al (2003) stated that peer advising relationships are helpful for students with disabilities and slow learning skills (p. 42).

\section{RESEARCH METHODOLOGY}

Initially a pilot study was conducted in order to develop a proper methodology and relevant modus operandi to collect the research data. A Survey instrument was designed to measure the attitudes of various students towards academic advising with 47 variables on a Likert scale of 1 to 7. Questionnaire was administered with 47 Questions to 50 respondents who were chosen at random in the Skyline College, Sharjah. The reliability analysis test revealed that the Cronbach alpha value is .7146 $>0.70$ as suggested by Nunally (1978). However, the number of factors was 18 (inconsistent factors without 
proper grouping). During the data collection stage it was also found that the respondents were having difficulty in interpreting 47 statements. It was also observed that issues like the role of developmental academic advising and learner centered education issues deserve to be deleted from the Questionnaire as wide fluctuations were observed on these items because of the semantic confusion with respect to rating of attitudes.

After reviewing the Pilot study, it was decided to confine the research to 35 variables and a new questionnaire was designed. The components in the Questionnaire were fine-tuned keeping in view of the experiences the researcher gained while conducting the pilot study. The deletion of 12 variables from the original questionnaire resulted in an increase in the coefficient alpha from .7146 to .781.This is within the accepted limits of reliability as suggested by Nunally (1978). The reliability analysis results for both original and modified questionnaires are displayed in Table 1. The frequency distribution of the response rate from three types of students chosen for this study, the response rate of students from two cities Dubai and Sharjah in UAE and the frequency distribution of male and female students are displayed in Table2, Table 3 and Table 4 respectively.

Table 1 Results of reliability test

\begin{tabular}{|l|l|l|}
\hline Overall reliability & Pilot test questionnaire & Study questionnaire \\
\hline Mean & 51.4333 & 104.57 \\
\hline Variance & 727.7713 & 419.21 \\
\hline Standard deviation & 26.9772 & 20.47 \\
\hline Number of variables & 47 & 35 \\
\hline Number of cases & 50 & 482 \\
\hline Cronbach Alpha $\alpha$ & 0.7146 & 0.781 \\
\hline
\end{tabular}

Table 2 Frequency distribution of response rate

\begin{tabular}{|l|l|l|l|l|}
\hline $\begin{array}{l}\text { Student-Groups } \\
\text { considered for study }\end{array}$ & Frequency & Percentage & $\begin{array}{l}\text { Valid } \\
\text { percentage }\end{array}$ & $\begin{array}{l}\text { Cumulative } \\
\text { percentage }\end{array}$ \\
\hline Business & 139 & 28.8 & 28.8 & 28.8 \\
\hline Tourism & 163 & 33.8 & 33.8 & 62.7 \\
\hline Information System & 180 & 37.3 & 37.3 & 100 \\
\hline Total & 482 & 100.0 & 100.0 & \\
\hline
\end{tabular}

Table 3 Frequency distribution of response rate in Dubai and Sharjah cities 


\begin{tabular}{|l|l|l|l|l|}
\hline $\begin{array}{l}\text { Cities considered } \\
\text { for the study }\end{array}$ & Frequency & Percentage & $\begin{array}{l}\text { Valid } \\
\text { percentage }\end{array}$ & $\begin{array}{l}\text { Cumulative } \\
\text { percentage }\end{array}$ \\
\hline Dubai & 276 & 57.3 & 57.3 & 57.3 \\
\hline Sharjah & 206 & 42.7 & 42.7 & 100.0 \\
\hline Total & 482 & 100.0 & 100.0 & \\
\hline
\end{tabular}

Table 4 Frequency distribution of Gender rate in Dubai and Sharjah cities

\begin{tabular}{|l|l|l|l|l|}
\hline Gender & Frequency & Percentage & Valid percentage & Cumulative percentage \\
\hline Male & 248 & 51.5 & 51.5 & 51.5 \\
\hline Female & 234 & 48.5 & 48.5 & 100.0 \\
\hline Total & 482 & 100.0 & 100.0 & \\
\hline
\end{tabular}

\section{Need and Importance of the Study}

The present study gains importance in the light of the increasing number of research studies that are being conducted by instructors through out the world on the issue academic advising. The changing attitude of students towards academic learning, hurdles faced by instructors while disseminating the learning inputs and the inability of the students to reach the goals of academic advising also validate the present study. The study is relevant in the light of the changing educational landscape created by the technological revolution in evolving efficient academic advising systems to foster higher student satisfaction.

\section{Objectives of the Study}

The broad objectives of the study are as following

- To understand and analyze the attitudes of undergraduate students in UAE towards academic advising.

- To identify and interpret the factors those are affecting academic advising in general and UAE colleges in particular.

- To test whether there is a significant difference between various factors affecting the academic advising with respect to various student groups considered for the present study? 


\section{Limitations of the Study}

The present research study is confined to selected colleges chosen from two cities Dubai and Sharjah in United Arab Emirates (UAE). Further, the study has incorporated only some statistical tools among the various tools that are available in this context. In particular the entire study adhered mainly to Factor Analysis, Analysis of Variance oneway (ANOVA-I WAY) classification and T-test for independent samples. In spite of the constant effort and care taken while administering the Questionnaires, some of the respondents were apprehending that this Questionnaire was designed by instructors to gauge their responses. However care was taken to nullify this apprehension among students. This marginally limited the study by delaying responses but had no bearing on the attitude measurement.

\section{Questionnaire and Sample}

To assess the attitude of undergraduate students' towards academic advising, a survey instrument of 35 variables was used. Respondents were asked to rate these 35 variables which are rooted on a seven point Likert scale of 1-7 where

1. Strongly disagree ( SD)

2. Disagree (D)

3. Tend to Disagree (TD)

4. Unsure (U)

5. Tend to Agree (TA)

6. Agree (A)

7. Strongly Agree (SA)

\section{Sample size and Data Collection}

The sample size is 482 . The sample includes students studying undergraduate courses in Dubai and Sharjah cities in UAE, drawn by simple random sampling from both sex groups (Male and Female).The respondents were chosen at random from Dubai Knowledge Village, Emirates College for Management and Information Technology (ECMIT), Dubai University College, Sharjah College and Skyline College. The primary data was collected by the survey instrument and Questionnaire was administered to the respondents directly by the researcher by visiting them in their respective colleges with the help of fellow instructors. The main sources of secondary sources include periodicals and journals, internet sources and magazines. Data collection took place from August 
2005 to October 2005. SPSS software (12.0 version) is used for the research analysis.

\section{Method}

Items (variables) were developed to capture respondents' feelings and emotions with respect to their attitudes towards the issue of academic advising. Principal Components Analysis (PCA) method was performed by varimax rotation with Kaiser Normalization to get percentage of variances for all the 35 variables so as to extract relevant factors reflecting the academic advising dimensions. Subsequently Analysis of variance- one way classification was performed for the extracted factors to test whether a significant difference exists between the various respondents (students from Business, Tourism and Information Systems) with respect to attitude towards academic advising. T- Test for independent samples was also performed to test whether there is a significant difference between male and female respondents within the extracted factors individually.

\section{Principal Components Analysis}

The responses of 482 respondents were entered into the PCA (Principal Components Analysis) of SPSS software wizard. The data is subjected to PCA (Principal Components Analysis) followed by varimax rotation with Kaiser Normalization to get a correlation matrix to get percentage of variances for all the 35 variables. The purpose is to identify the variables with eigen value more than 1 and to identify the relevant factors which can be extracted from the analysis (Cudeck et al, (1994)). It can be interpreted from the cumulative percentage column in Table 5 (Results of Principal axis factoring) that seven factors are extracted that accounted for 72.663 percent of the total variance (information contained in the original 35 variables) and this value is acceptable for further analysis.

A Rotated Component Matrix Table is generated. Table 6 (Rotated component Matrix for 7 extracted factors) displays the loading of each variable on each of the extracted factors. This is similar to a correlation matrix with loadings having a value between 0 and 1 . Values close to 1 and above .50 represent high loadings. The objective is to find variables which have high loading on one factor but low loadings on other factors. Loadings above .50 are considered. The objective of this research is to identify the right set of variables influencing the attitudes towards academic advising. It is observed that not all the variables are influencing the issue of academic advising. A detailed explanation of the List of Factors with Variables and Factor Loadings is displayed in Table 7. 
Table 5 Results of principal axis factoring and total variance

\begin{tabular}{|c|c|c|c|}
\hline Factor & Eigen value & Percentage of variance & $\begin{array}{c}\text { Cumulative variance - } \\
\text { percentage }\end{array}$ \\
\hline 1 & 6.114 & 17.468 & 17.468 \\
\hline 2 & 4.706 & 13.445 & 30.913 \\
\hline 3 & 4.206 & 12.018 & 42.931 \\
\hline 4 & 3.423 & 9.779 & 52.710 \\
\hline 5 & 2.740 & 7.829 & 60.539 \\
\hline 6 & 2.249 & 6.246 & 66.965 \\
\hline 7 & 1.994 & 5.698 & 72.663 \\
\hline
\end{tabular}

Table 6 Rotated component matrix

\begin{tabular}{|l|c|c|c|c|c|c|c|}
\hline \multirow{2}{*}{ Variable } & \multicolumn{7}{|c|}{ Component } \\
\cline { 2 - 8 } & 1 & 2 & 3 & 4 & 5 & 6 & 7 \\
\hline A18 & .867 & .070 & .118 & -.041 & -.0680 & .054 & .007 \\
\hline A27 & .858 & -.105 & -.026 & .336 & -.050 & -.075 & -.024 \\
\hline A35 & .798 & .149 & .114 & -.057 & .309 & -.082 & -.081 \\
\hline A30 & .798 & .149 & .114 & -.057 & .309 & -.082 & -.081 \\
\hline A28 & .588 & -.022 & .026 & .564 &.-449 & -.059 & -.160 \\
\hline A3 & .509 & -.111 & .335 & -.117 & -.123 & .047 & .206 \\
\hline A9 & .195 & .797 & .095 & .046 & .314 & .123 & .120 \\
\hline A21 & .229 & .793 & .230 & .077 & -.142 & .080 & -.033 \\
\hline A24 & -.030 & .780 & -.100 & -.044 & .120 & -.115 & -.216 \\
\hline A19 & -.285 & .747 & -.070 & -.278 & -.180 & -.015 & .075 \\
\hline A13 & .158 & .658 & -.297 & -.033 & -.347 & .438 & .031 \\
\hline A11 & -.008 & .611 & -.046 & .034 & -.108 & .278 & .256 \\
\hline A22 & .164 & .117 & .887 & -.113 & .009 & -.020 & .209 \\
\hline A1 & -.081 & .029 & .771 & -.061 & .042 & -.126 & -.007 \\
\hline A8 & .324 & -.061 & .728 & .052 & .184 & -.014 & -.094 \\
\hline A2 & .019 & -.102 & .720 & .207 & .069 & .446 & -.236 \\
\hline A7 & .398 & -.320 & .685 & .118 & -.232 & .191 & .017 \\
\hline A10 & .255 & .263 & .586 & .235 & .527 & .055 & .042 \\
\hline
\end{tabular}


Table 6 Rotated component matrix (Continued)

\begin{tabular}{|l|c|c|c|c|c|c|c|}
\hline \multirow{2}{*}{ Variable } & \multicolumn{7}{|c|}{ Component } \\
\cline { 2 - 8 } & 1 & 2 & 3 & 4 & 5 & 6 & 7 \\
\hline A29 & -.001 & -.127 & .171 & .837 & -.79 & .201 & -.040 \\
\hline A16 & .272 & .076 & .067 & .805 & -.283 & -.105 & .131 \\
\hline A34 & .068 & -.107 & .068 & -.717 & -.386 & -102 & -.183 \\
\hline A17 & .504 & .073 & .106 & -.659 & .071 & .061 & .175 \\
\hline A15 & .225 & -.043 & .125 & -.585 & .409 & .348 & -.366 \\
\hline A12 & .112 & -.016 & -.013 & .444 & .128 & -.042 & -.298 \\
\hline A26 & .262 & -.191 & -.060 & -.271 & .775 & .038 & .002 \\
\hline A25 & -.034 & .125 & .249 & .096 & .693 & -.163 & -.104 \\
\hline A20 & -.155 & .29 & .515 & -.097 & -.523 & .151 & -.433 \\
\hline A14 & .019 & .410 & .068 & .109 & -.467 & -.220 & -.122 \\
\hline A4 & -.178 & .196 & -.052 & .154 & .073 & .709 & .173 \\
\hline A23 & -.183 & .527 & .134 & .249 & .048 & -.638 & .177 \\
\hline A32 & -.065 & .182 & .329 & .090 & -.279 & .637 & -.381 \\
\hline A31 & .008 & .264 & .315 & -.307 & .099 & .506 & .264 \\
\hline A5 & .256 & .253 & -.042 & .074 & -.157 & .029 & .712 \\
\hline A6 & .445 & -.068 & .061 & .035 & .220 & .307 & .544 \\
\hline A33 & .319 & -.172 & .109 & -.292 & .277 & -.230 & .516 \\
\hline
\end{tabular}


Table 7 List of factors with variables and factor loadings

\begin{tabular}{|c|c|c|c|}
\hline Factor & Item & Variables & $\begin{array}{c}\text { Factor } \\
\text { loadings }\end{array}$ \\
\hline \multirow{6}{*}{$\begin{array}{l}\text { Factor -I: } \\
\text { Student } \\
\text { Oriented }\end{array}$} & A18 & $\begin{array}{l}\text { My advisor displays positive attitude towards } \\
\text { advisee's problems. }\end{array}$ & .867 \\
\hline & A27 & $\begin{array}{l}\text { My advisor has a good perspective of what I am all } \\
\text { about. }\end{array}$ & .858 \\
\hline & A35 & I feel that my advisor enjoys his advising job. & .798 \\
\hline & $\mathrm{A} 30$ & $\begin{array}{l}\text { My advisor is keen on meeting his advisees on a } \\
\text { frequent basis. }\end{array}$ & .798 \\
\hline & $\mathrm{A} 28$ & $\begin{array}{l}\text { My advisor displays concern for his advisees } \\
\text { whose GPA is low. }\end{array}$ & .588 \\
\hline & A3 & $\begin{array}{l}\text { My advisor has a good grasp of the problems faced } \\
\text { by his advisees. }\end{array}$ & .509 \\
\hline \multirow[b]{4}{*}{ Factor -II: } & A9 & $\begin{array}{l}\text { My advisor is aware of the details in the college } \\
\text { catalogue. }\end{array}$ & .797 \\
\hline & $\mathrm{A} 21$ & $\begin{array}{l}\text { My advisor contacts the parents of his advises } \\
\text { whenever there is a need. }\end{array}$ & .793 \\
\hline & A24 & $\begin{array}{l}\text { My advisor communicates in a clear and } \\
\text { unambiguous manner with his advisees. }\end{array}$ & .780 \\
\hline & A19 & $\begin{array}{l}\text { My advisor develops programs to facilitate advisee } \\
\text { and advisor interactions. }\end{array}$ & .747 \\
\hline \multirow{5}{*}{$\begin{array}{l}\text { Task } \\
\text { Oriented }\end{array}$} & A13 & $\begin{array}{l}\text { My advisor focuses on peer group interactions } \\
\text { amongst the advisees. }\end{array}$ & .658 \\
\hline & A11 & $\begin{array}{l}\text { My advisor identifies the strengths and weaknesses } \\
\text { of his advisees. }\end{array}$ & .611 \\
\hline & A 22 & $\begin{array}{l}\text { My advisor helps in evaluating the progress } \\
\text { towards academic goals. }\end{array}$ & .887 \\
\hline & A1 & $\begin{array}{l}\text { My advisor helps his advisees in exploring career } \\
\text { goals. }\end{array}$ & .771 \\
\hline & A8 & My advisor knows my friends and my peer group. & .728 \\
\hline \multirow{4}{*}{$\begin{array}{l}\text { Factor-III: } \\
\text { System } \\
\text { Oriented }\end{array}$} & A2 & $\begin{array}{l}\text { My advisor conducts surveys to assess the } \\
\text { academic advising effectiveness. }\end{array}$ & .720 \\
\hline & A7 & $\begin{array}{l}\text { My advisor strongly discourages Internet } \\
\text { Plagiarism. }\end{array}$ & .685 \\
\hline & A10 & $\begin{array}{l}\text { My advisor is aware of the current changes and } \\
\text { policies of the college. }\end{array}$ & .586 \\
\hline & A29 & $\begin{array}{l}\text { My advisor projects positive image about the } \\
\text { courses offered by the college. }\end{array}$ & .837 \\
\hline
\end{tabular}


Table 7 List of factors with variables and factor loadings (Continued)

\begin{tabular}{|c|c|c|c|}
\hline Factor & Item & Variables & $\begin{array}{l}\text { Factor } \\
\text { loadings }\end{array}$ \\
\hline \multirow{4}{*}{$\begin{array}{l}\text { Factor }-I V: \\
\text { Technology } \\
\text { Oriented }\end{array}$} & A16 & My advisor quickly replies to my emails. & .805 \\
\hline & A34 & $\begin{array}{l}\text { My advisor encourages his advisees to refer online } \\
\text { journals and other web resources. }\end{array}$ & .717 \\
\hline & A17 & $\begin{array}{l}\text { My advisor updates his web site frequently and } \\
\text { posts messages on academic advising. }\end{array}$ & .659 \\
\hline & A 15 & $\begin{array}{l}\text { My advisor encourages his advisees to use } \\
\text { technology for class room presentations. }\end{array}$ & .585 \\
\hline \multirow{3}{*}{$\begin{array}{l}\text { Factor -V: } \\
\text { Extra } \\
\text { Curricular } \\
\text { Oriented }\end{array}$} & A26 & $\begin{array}{l}\text { My advisor is aware of the role of extra curricular } \\
\text { activities in the student development. }\end{array}$ & .775 \\
\hline & A25 & $\begin{array}{l}\text { My advisor encourages community service } \\
\text { activities. }\end{array}$ & .693 \\
\hline & A20 & $\begin{array}{l}\text { My advisor encourages his advisees to participate } \\
\text { in inter college competitions, industrial and } \\
\text { educational exhibitions. }\end{array}$ & .523 \\
\hline \multirow{3}{*}{$\begin{array}{l}\text { Factor }-V I: \\
\text { Innovation } \\
\text { Oriented }\end{array}$} & A23 & $\begin{array}{l}\text { My advisor uses positive open-ended questions to } \\
\text { draw out what students feel about the college, } \\
\text { courses and their peer group. }\end{array}$ & .638 \\
\hline & A32 & $\begin{array}{l}\text { My advisor conducts one -on- one chat sessions } \\
\text { with individual advisees and open chat rooms for } \\
\text { group of advisees. }\end{array}$ & .637 \\
\hline & A31 & $\begin{array}{l}\text { My advisor ensures that transfer students tour the } \\
\text { college campus and become familiar with } \\
\text { important campus offices. }\end{array}$ & .506 \\
\hline $\begin{array}{l}\text { Factor-VII: } \\
\text { Non Serious } \\
\text { Advisor }\end{array}$ & A6 & My adviser avoids meeting his advises. & .544 \\
\hline
\end{tabular}

INTERPRETATION OF THE PRINCIPAL COMPONENTS

It can be interpreted from the Principal components analysis that the attitudes of UAE undergraduate students towards academic advising can be understood in terms of the seven Factors extracted below. The extracted factors are as following.

\section{Factor I: Student Oriented Advisors}

This factor reflected the attitude of the UAE undergraduate students towards the student oriented attitude of their academic advisor. The factor analysis findings revealed 
that this explained by six variables like A18, A27, A35, A30, A28 and A3. The findings further revealed that the advisees felt that their academic advisor displayed a positive attitude towards their problems and has a good perspective of what they are all about. It is interesting to note that they felt that the advisor was enjoying his academic advising duties, met his advisees on a frequent basis and possessed a good grasp of the problems faced by the advisees. They further felt that their advisor displayed a concern for advisees whose GPA was less.

\section{Factor II: Task Oriented Advisors}

This factor reflected the attitude of the UAE undergraduate students towards the task orientation of the academic advisor. The factor analysis findings revealed that this is explained by nine variables like A9, A21, A24, A19, A13, A11, A22, A1 and A8. The findings further revealed that their academic advisor is aware of the details mentioned in the catalogue, contacted their parents on a regular basis whenever there is a need, communicated clearly in an unambiguous manner with his advisees, developed programs to facilitate advisee and advisor interactions and focused on peer group interactions among the advisees. They further felt that their advisor identified the strengths and weaknesses of his advisees and helped in evaluating the progress towards academic goals and career goals. They also felt that their academic advisor is aware of the peer group influence on the advisees.

\section{Factor III: System Oriented Advisors}

This factor reflected the attitude of the UAE undergraduate students towards the system orientation of the academic advisor. The factor analysis findings revealed that this is explained by four variables like A2, A7, A10 and A16. The findings also revealed that the academic advisors conducted surveys to assess the academic advising effectiveness and strongly discouraged internet plagiarism. The findings further revealed that the academic advisor was aware of the current changes and policies of the college and knew the peer groups that influenced their advisees.

\section{Factor IV: Technology Oriented Advisors}

This factor reflected the attitude of the UAE undergraduate students towards the academic advisors in terms of the orientation towards technology. The factor analysis findings revealed that this is explained by four variables like A16, A34, A17and A15.The 
findings also revealed that the academic advisors replied to the advisees' emails quickly and encouraged advisees to read online journals and other web resources. It was also observed that the academic advisor frequently updated his web site and posted messages on academic advising. It was further revealed that the academic advisor encouraged his advisees to use technology for the class room presentations.

\section{Factor V: Extra Curricular Activities Oriented Advisors}

This factor reflected the attitude of the UAE undergraduate students towards the academic advisors in terms of the orientation towards extra curricular activities. The factor analysis findings revealed that this is explained by three variables like A26, A25 and A20. The findings also revealed that the academic advisor was aware of the role of extra curricular activities in the student development, and encouraged his advisees to participate in community service activities. The research findings also revealed that the academic advisor encouraged his advisees to participate in inter college student competitions and other similar events.

\section{Factor VI: Innovation Oriented Advisors}

This factor reflected the attitude of the UAE undergraduate students towards the academic advisors in terms of the orientation towards innovative activities. The factor analysis findings revealed that this is explained by three variables like A23, A32 and A31. The findings also revealed that the academic advisor used positive open ended questions to draw out what the advisees felt about the courses, college and peer group. It was also observed that the academic advisor conducted one to one chat sessions with individual and groups and ensured that the transfer students toured the college to become familiar with the campus facilities.

\section{Factor VII: Non Serious Advisors}

This factor reflected the attitude of the UAE undergraduate students towards the academic advisors in terms of the non serious attitude. The factor analysis findings revealed that this is explained by one variable titled as A6. The findings also revealed that the academic advisor avoided meeting his advisees demonstrated his casual and nonserious attitude. 


\section{ANALYSIS OF VARIANCE ONE-WAY CLASSIFICATION AND INTERPRETATION}

Analysis of variance one way classification test was performed for the above 7 extracted factors to test whether there is a significant difference between the three types of students chosen for the study (Business, Tourism and Information Systems). Both Null and Alternate hypotheses were formulated for each factor. Null Hypothesis is denoted by $\mathrm{HO}$ and alternate Hypothesis is denoted by H1. The results are displayed in Table 8. (Analysis of variance one way between seven extracted factors)

HO: There is no significant difference between the three types of students chosen for this study (Business, Tourism and Information Systems).

H1: There is a significant difference between the three types of students chosen for this study (Business, Tourism and Information Systems).

Table 8 ANOVA one-way classification of seven extracted Factors

\begin{tabular}{|c|c|c|c|c|c|c|}
\hline \multicolumn{2}{|l|}{ Factor } & $\begin{array}{l}\text { Sum of } \\
\text { squares }\end{array}$ & $d f$ & $\begin{array}{l}\text { Mean } \\
\text { square }\end{array}$ & $\mathrm{F}$ & Sig. \\
\hline \multirow{3}{*}{$\begin{array}{l}\text { Student } \\
\text { Centered }\end{array}$} & $\begin{array}{l}\text { Between } \\
\text { groups }\end{array}$ & .961 & 2 & .481 & \multirow{3}{*}{479} & \multirow{3}{*}{.619} \\
\hline & $\begin{array}{l}\text { Within } \\
\text { groups }\end{array}$ & 480.039 & 479 & 1.002 & & \\
\hline & Total & 481.000 & 481 & & & \\
\hline \multirow{3}{*}{$\begin{array}{l}\text { Task } \\
\text { Oriented }\end{array}$} & $\begin{array}{l}\text { Between } \\
\text { groups }\end{array}$ & 1.291 & 2 & .646 & \multirow{3}{*}{.645} & \multirow{3}{*}{.525} \\
\hline & $\begin{array}{l}\text { Within } \\
\text { groups }\end{array}$ & 479.709 & 479 & 1.001 & & \\
\hline & Total & 481.000 & 481 & & & \\
\hline \multirow{3}{*}{$\begin{array}{l}\text { System } \\
\text { Oriented }\end{array}$} & $\begin{array}{l}\text { Between } \\
\text { groups }\end{array}$ & 4.041 & 2 & $\begin{array}{l}1.506 \mathrm{E}- \\
02\end{array}$ & \multirow{3}{*}{.015} & \multirow{3}{*}{1.000} \\
\hline & $\begin{array}{l}\text { Within } \\
\text { groups }\end{array}$ & 476.959 & 479 & 1.003 & & \\
\hline & Total & 481.000 & 481 & & & \\
\hline \multirow{3}{*}{$\begin{array}{l}\text { Technology } \\
\text { Oriented }\end{array}$} & $\begin{array}{l}\text { Between } \\
\text { groups }\end{array}$ & 2.334 & 2 & 1.167 & \multirow{3}{*}{1.168} & \multirow{3}{*}{.312} \\
\hline & $\begin{array}{l}\text { Within } \\
\text { groups }\end{array}$ & 478.666 & 479 & .996 & & \\
\hline & Total & 481.000 & 481 & & & \\
\hline
\end{tabular}


Table 8 ANOVA one-way classification of seven extracted Factors (Continued)

\begin{tabular}{|c|c|c|c|c|c|c|}
\hline \multicolumn{2}{|l|}{ Factor } & $\begin{array}{l}\text { Sum of } \\
\text { squares }\end{array}$ & $\mathrm{df}$ & $\begin{array}{l}\text { Mean } \\
\text { square }\end{array}$ & $\mathrm{F}$ & Sig. \\
\hline \multirow{3}{*}{$\begin{array}{l}\text { Extra- } \\
\text { Curricular } \\
\text { Oriented }\end{array}$} & $\begin{array}{l}\text { Between } \\
\text { groups }\end{array}$ & .103 & 2 & .052 & \multirow{3}{*}{.051} & \multirow{3}{*}{.950} \\
\hline & $\begin{array}{l}\text { Within } \\
\text { groups }\end{array}$ & 480.897 & 479 & 1.004 & & \\
\hline & Total & 481.000 & 481 & & & \\
\hline \multirow{3}{*}{$\begin{array}{l}\text { Innovation } \\
\text { Oriented }\end{array}$} & $\begin{array}{l}\text { Between } \\
\text { groups }\end{array}$ & .360 & 2 & .180 & \multirow{3}{*}{.180} & \multirow{3}{*}{.836} \\
\hline & $\begin{array}{l}\text { Within } \\
\text { groups }\end{array}$ & 480.640 & 479 & 1.003 & & \\
\hline & Total & 481.000 & 481 & & & \\
\hline \multirow{3}{*}{$\begin{array}{l}\text { Non-Serious } \\
\text { Adviser }\end{array}$} & $\begin{array}{l}\text { Between } \\
\text { groups }\end{array}$ & 1.302 & 2 & .651 & \multirow{3}{*}{.650} & \multirow{3}{*}{.522} \\
\hline & $\begin{array}{l}\text { Within } \\
\text { groups }\end{array}$ & 479.698 & 479 & .1 .001 & & \\
\hline & Total & 481.000 & 481 & & & \\
\hline
\end{tabular}

\section{Interpretation}

For factor I "Student Oriented Advisors", it can be interpreted that the F- Probability value in the Anova is .619, which is more than .05(level of significance), hence the null hypothesis (at 95\% confidence level) is accepted. It can be inferred that there is no significant difference between the three types of groups chosen for the study (Business, Tourism and Information Systems) for Factor I and the test is not significant at 5\% level of confidence.

For factor II "Task Oriented Advisors", it can be interpreted that the F- Probability value in the Anova is .525 , which is more than .05(level of significance), hence the null hypothesis (at 95\% confidence level) is accepted. It can be inferred that there is no significant difference between the three types of groups chosen for the study (Business, Tourism and Information Systems) for Factor II and the test is not significant at 5\% level of confidence.

For factor III "System Oriented Advisors", it can be interpreted that the FProbability value in the Anova is 1.00 , which is more than .05 (level of significance), hence the null hypothesis (at 95\% confidence level) is accepted. It can be inferred that there is no significant difference between the three types of groups chosen for the study 
(Business, Tourism and Information Systems) for Factor III and the test is not significant at $5 \%$ level of confidence.

For factor IV "Innovation Oriented Advisors", it can be interpreted that the FProbability value in the Anova is .312 which is more than .05(level of significance), hence the null hypothesis (at 95\% confidence level) is accepted. It can be inferred that there is no significant difference between the three types of groups chosen for the study (Business, Tourism and Information Systems for Factor IV and the test is not significant at $5 \%$ level of confidence.

For factor V "Extra Curricular Activities Oriented Advisors", it can be interpreted that the F- Probability value in the Anova is .950, which is more than .05 (level of significance), hence the null hypothesis (at $95 \%$ confidence level) is accepted. It can be inferred that there is no significant difference between three types of groups chosen for the study (Business, Tourism and Information Systems for Factor V and the test is not significant at $5 \%$ level of confidence.

For factor VI "Innovation Oriented Advisors", it can be interpreted that the FProbability value in the Anova is .836 , which is more than .05 (level of significance), hence the null hypothesis (at 95\% confidence level) is accepted. It can be inferred that there is no significant difference between three types of groups chosen for the study (Business, Tourism and Information Systems for Factor VI and the test is not significant at $5 \%$ level of confidence.

For factor VII "Non Serious Advisors", it can be interpreted that the F- Probability value in the Anova is .522, which is more than .05(level of significance), hence the null hypothesis (at 95\% confidence level) is accepted. It can be inferred that there is no significant difference between three types of groups chosen for the study (Business, Tourism and Information Systems for Factor VII and the test is not significant at 5\% level of confidence.

\section{T-TEST TO FIND WHETHER THERE IS ANY SIGNIFICANT DIFFERENCE BETWEEN MALE AND FEMALE RESPONDENTS WITH RESPECT ACADEMIC ADVISING}

In order to test, whether the attitudes of sample of respondents towards academic advising differ according to Gender, an independent t-test was performed on all the extracted factors. The findings revealed that no significant differences were noticed among the male and female respondents with respect to the seven extracted factors. In 
this context, Null Hypothesis is denoted by $\mathrm{HO}$ and alternate Hypothesis is denoted by H1. The results are displayed in Table 9. (T-Test for Male and Female groups)

HO: There is no significant difference between the male and female respondents for a given factor with respect to attitudes towards academic advising.

H1: There is significant difference between the male and female respondents for a given factor with respect to attitudes towards academic advising.

Table 9 Results of T- Test for Male and Female groups

\begin{tabular}{|c|c|c|c|c|c|c|c|}
\hline Factors & Gender & $\mathbf{N}$ & Mean & S.D & $T$ & DF & $\mathbf{P}$ \\
\hline $\begin{array}{l}\text { Student } \\
\text { Centered }\end{array}$ & $\begin{array}{l}\text { Male } \\
\text { Female }\end{array}$ & $\begin{array}{l}248 \\
234\end{array}$ & $\begin{array}{l}.0285646 \\
-.0302736\end{array}$ & $\begin{array}{l}1.01903434 \\
.98069507\end{array}$ & .645 & 480 & .519 \\
\hline $\begin{array}{l}\text { Task } \\
\text { Oriented } \\
\end{array}$ & $\begin{array}{l}\text { Male } \\
\text { Female }\end{array}$ & $\begin{array}{l}248 \\
234 \\
\end{array}$ & $\begin{array}{l}-.0059632 \\
.0063200 \\
\end{array}$ & $\begin{array}{l}1.0022 \\
.9997 \\
\end{array}$ & -.135 & 480 & .893 \\
\hline $\begin{array}{l}\text { System } \\
\text { Oriented }\end{array}$ & $\begin{array}{l}\text { Male } \\
\text { Female }\end{array}$ & $\begin{array}{l}248 \\
234\end{array}$ & $\begin{array}{l}.0141805 \\
-.0150289\end{array}$ & $\begin{array}{l}.96601 \\
1.00684\end{array}$ & .320 & 480 & .749 \\
\hline $\begin{array}{l}\text { Technology } \\
\text { Oriented }\end{array}$ & $\begin{array}{l}\text { Male } \\
\text { Female }\end{array}$ & $\begin{array}{l}248 \\
234 \\
\end{array}$ & $\begin{array}{l}-.0080853 \\
.0085691\end{array}$ & $\begin{array}{l}1.0068 \\
.99477\end{array}$ & -.183 & 480 & .855 \\
\hline $\begin{array}{l}\text { Extra- } \\
\text { Curricular } \\
\text { Oriented }\end{array}$ & $\begin{array}{l}\text { Male } \\
\text { Female }\end{array}$ & $\begin{array}{l}248 \\
234\end{array}$ & $\begin{array}{l}-.0183340 \\
.0194309\end{array}$ & $\begin{array}{l}1.0068 \\
.99452\end{array}$ & -.414 & 480 & .679 \\
\hline $\begin{array}{l}\text { Innovation } \\
\text { Oriented }\end{array}$ & $\begin{array}{l}\text { Male } \\
\text { Female }\end{array}$ & $\begin{array}{l}248 \\
234\end{array}$ & $\begin{array}{l}-.0240846 \\
.0255256\end{array}$ & $\begin{array}{l}.9833 \\
1.0188\end{array}$ & -.544 & 480 & .587 \\
\hline $\begin{array}{l}\text { Non-Serious } \\
\text { Adviser }\end{array}$ & $\begin{array}{l}\text { Male } \\
\text { Female }\end{array}$ & $\begin{array}{l}248 \\
234\end{array}$ & $\begin{array}{l}.0325907 \\
-.0345406\end{array}$ & $\begin{array}{l}1.019 \\
.9802\end{array}$ & .736 & 480 & .480 \\
\hline
\end{tabular}

\section{Interpretation}

The analytical results of t-test revealed that there is no significant difference between male and female respondents towards mobile advertising. The mean values for seven extracted factors also demonstrated that there is no significant difference. Since the p-values like $.519, .893, .749, .855, .679, .587$ and .480 are $>.05$ (at $5 \%$ level of significance), hence the null hypothesis is accepted (Table 9). So, it can be interpreted that there is no significant difference between male and female respondents with regard to their attitude towards academic advising. 


\section{SUGGESTIONS TO IMPROVE ADVISING EFFECTIVENESS}

After reviewing the findings of the present study, the following suggestions are made for the successful academic advising. They include:

\section{Stop complaining}

Academic advisors may need to accept the students as part of the college/university population and may also make efforts to move on. Complaining and criticizing students (advisees) can demean academic advisors' morale and motivation to help those deserving group of advisees who may need an immediate intervention. Keeping the complaints to a minimum will create a congenial academic advising climate in the college campus.

\section{Change the delivery of service}

The students may need more individualized attention and therefore herding them into large groups may not be effective. Using smaller groups or individual sessions to reach a diverse set of advisees may yield the desired results. If there is a lack of staff to keep up with demands, using peer advisers for support is emerging as a major option by many advisors. In addition to this, using more visuals may prove to be effective in reaching the advisees at the under graduate levels. Some advisees may take one of every flyer and seldom read any of the information on them. In these cases, using video presentations may stimulate interest and help them answering some questions before they sit across the desk of the academic advisor. A simple welcome video or PowerPoint presentation may work well.

\section{Teach life skills}

Since decision-making skills and self-advocacy skills may be lacking in undergraduate students, advisors may need to take an active role in teaching these skills. If this is not done effectively, the same advisees may be back next semester, probably with the same set of questions. Although advisees may be in the need of all the crucial information, promoting critical-thinking strategies to encourage them to make their own decisions may go a long away in orienting them towards academic advising goals. At this juncture the advisor may need to dig deep to find the relevant counselor skills, which may reduce the confusion of advisees. 


\section{Be honest with students}

Being honest with the students on issues like academic policies, rules of promotion, scholarship avenues and placement opportunities plays a vital role in creating a positive image about the academic advising systems. There may exist a bunch of students who feel pressurized, while coming to a college for economic, social, or professional reasons and may sometimes seek a solace in the academic adviser on various academic and nonacademic issues. Academic advisors play a critical role in this context.

\section{Provide excellent hands-on training for new advisers}

Educating new employees (Instructors) on what senior advisors know about the college/university population with an objective opinion on the diversified groups of students helps in creating effective advising systems. Experienced advisors avoid giving new advisers preconceived notions about their advisees. It is observed that, students often meet the expectations set by an advisor when realistic goals are set for their advisees. Therefore, academic advisors may collectively devise those expectations which are realistic and attainable keeping in view of the diversified set of students.

\section{CONCLUSION}

Technological advances are fundamentally changing the way colleges and universities operate and have implications for the delivery of academic advising services. In this context, academic advising plays a major role in facilitating student satisfaction and therefore, its importance needs to be conveyed to all stakeholders in the institution. It can be interpreted from the analysis of the present research findings that the attitudes of respondents chosen from three types of students (Business, Tourism and Information Systems) is reflected in terms of the seven factors like Student Oriented Advisors, Task Oriented Advisors, System Oriented Advisors, Technology Oriented Advisors, Extra Curricular Activities Oriented Advisors, Innovation Oriented Advisors and Non Serious Advisors. It can also be inferred from the above analysis that the extracted seven factors together accounted for $72.663 \%$ of the total variance (information contained in the original 35 variables). This demonstrated the efficacy of the survey instrument as only about $22.337 \%$ of information is lost. This is acceptable keeping in view of the large number of variables considered for the research. It can also be inferred that the survey has economized on the number of variables from 35 to 7 factors which looks simple to interpret and easy to understand with respect to the attitudes of advisees towards 
academic advising. It is interesting to note that there is no significant difference between the respondents attitude with regard to academic advising from the three selected categories of respondents (Business, Tourism and Information Systems) within the seven extracted factors. The results further revealed that there is no significant difference between the male and female segments as well with respect to academic advising within the seven extracted factors. This has major implications for academic advisors who aim at delivering a better advising service.

\section{REFERENCES}

Alexitch, L. R. (2002). The Role of Help-Seeking Attitudes and Tendencies in Students' Preferences for Academic Advising, Journal of College Student Development, 43(1), 5-14.

Brown, K. L. (2003). From Teacher-Centered To Learner-Centered Curriculum: Improving Learning in Diverse Classrooms, Education, 124(1), 49-54.

Cudeck, Robert, \& O'Dell, Lisa L. (1994). Applications of Standard Error Estimates in Unrestricted Factor Analysis: Significance Tests for Factor Loadings and Correlations. Psychological Bulletin, 115, 475-487.

Davis, J. S., and Cooper, D. L. (2001). Assessing Advising Style: Student Perceptions of Academic Advisors. College Student Affairs Journal, 20(2), 53-61.

Edwards, C. E., \& Murdock, N. L. (1994). Characteristics of Therapist Self-Disclosure in the Counseling Process, Journal of Counseling and Development, 72(4), 358-389.

Habley, Wes. (1981). Academic Advising: Critical Link in Student Retention, NASPA Journal, 28(4): 45-50.

Hamrick, F. A., Evans, N. J, and Schuh, J. H. (2002). Foundations Of Student Affairs Practice: How Philosophy, Theory, And Research Strengthen Educational Outcomes, San Francisco: Jossey-Bass.

Hendey, W. G. (1999). Developmental Advising: A Practical View, The Mentor: An Academic Advising Journal, 1(1).

Kadar, R. S. (2001). A Counseling Liaison Model of Academic Advising, Journal of College Counseling, 4(2), 174-178.

Light, R. J. (2001). Making The Most Of College, Students Speak Their Minds, Cambridge, Harvard University Press.

Light, R. (2001). Making The Most Of College: Students Speak Their Minds, Cambridge, MA: Harvard University Press. 
McConnell, Peggy J. (2000). What Community Colleges Should Do To Assist FirstGeneration Students, Community College Review.28 (3), 75-87.

Milem, J. F., Berger, J. B., and Dey, E. L. (2000). Faculty Time Allocation, The Journal of Higher Education, 71(4), 454-475.

Moneta, L. (1997). The Integration of Technology with the Management of Student Services: New Directions for Student Services: Using Technology to Promote, Student Learning, 78, 5-16.

Nunnally, Jum C. (1978). Psychometric theory (2nd ed.). New York: McGraw-Hill.

Scott, P. (2000). Globalization and Higher Education: Challenges for the 21st Century, Journal of Studies in International Education. Vol 4. No.1.

Vijaya Kumar Gudep (2005). Globalization and Higher Education: Emerging HR Challenges and Benchmarking Issues before Universities in the 21st Century, Skyline Business Journal, Sharjah, United Arab Emirates, Volume1-No.2, Spring 2005

Walters, Evon Washington. (2003). Editor's Choice: Becoming Student Centered via the One-Stop Shop Initiative: A Case Study of Onondaga Community College, Community College Review, 31 (3), 40-54.

Whelley, T., Radtke, R., Burgstahler, S and Christ, T. (Autumn, 2003). Mentors, Advisers, Role Models, Peer Supporters: Career Development Relationships and Individuals with Disabilities, American Rehabilitation, 27(1), 42-49.

Watkins, C. E. (1990). The Effects of Counselor Self-Disclosure: A Research Review, The Counseling Psychologist, 18, 477-500. 